\title{
Desain Proteksi Katodik pada Struktur Baja di Laut dan di Darat untuk Masa Layan 10 Tahun
}

\author{
D. Sumantri* dan P. T. Iswanto \\ Departemen Teknik Mesin dan Industri, Fakultas Teknik, Universitas Gadjah Mada. \\ Jl. Grafika No. 2, Kompleks UGM, Yogyakarta 55281, Indonesia \\ *e-mail: dian.sumantri@ymail.com
}

\begin{abstract}
Abstrak
Korosi menjadi masalah yang paling sering terjadi pada struktur logam baik yang berada di darat maupun laut. Untuk struktur baja seperti tangki minyak di darat masalah korosi yang sering timbul adalah di bagian bawah tangki, sedangkan tower sutet yang berada di daerah laut korosi yang timbul adalah bagian yang terkena air laut. Hal ini terjadi karena struktur mengalami contact dengan air laut ataupun tanah sebagai elektrolit. Kerusakan akibat korosi pada struktur logam bisa menyebabkan banyak kerugian seperti biaya perbaikan dan instalasi ulang, kerusakan lingkungan atau kecelakaan kerja. Oleh karena itu, sangat penting untuk bisa melindungi struktur baja dari bahaya korosi. Salah satu perlindungan korosi yang populer adalah proteksi katodik, baik dengan metoda arus paksa yang juga dikenal dengan ICCP (Impressed Current Cathodic Protection) maupun metoda anoda korban atau SACP (Sacrifical Anode Cathodic Protection). Penelitian ini bertujuan untuk melakukan perancangan proteksi katodik dengan metoda arus paksa (ICCP) untuk tangki minyak mentah di darat (onshore) dan perancangan proteksi katodik untuk tower sutet di laut (offshore). Penelitian ini diawali dengan studi literatur, kemudian dilanjutkan dengan tahap pengumpulan data, baik data primer maupun data sekunder. Dilanjutkan dengan tahap desain ICCP tangki minyak mentah di darat dan desain SACP tower sutet di laut. Setelah desain ICCP dan SACP selesai dilanjutkan dengan tahap desain instalasi. Hasil desain ICCP tangki minyak mentah membutuhkan 4 anoda Tubular MMO Titanium dengan kapasitas trafo $3.02 \mathrm{kVA}$ dan tegangan DC 24 volt. Sedangkan untuk desain SACP tower sutet membutuhkan 4 anoda Al-Zn-In Alloy dan berat masing-masing anoda $25 \mathrm{~kg}$ dengan kapasitas anoda $2464 \mathrm{~A} . \mathrm{hr} / \mathrm{kg}$.
\end{abstract}

Kata kunci : korosi, proteksi katodik, arus paksa, anoda korban.

\begin{abstract}
Corrosion is the most common problem in metal structures both on land and at sea. For steel structures such as oil tanks on land, the corrosion problem that often arises is at the bottom of the tank, while the sutet tower in the sea area which arises is the part that is exposed to sea water. This happens because the structure has contact with sea water or land as an electrolyte. Damage due to corrosion on metal structures can cause many losses such as the cost of repairs and reinstallation, environmental damage or work accidents. Therefore, it is very important to be able to protect steel structures from corrosion. One popular corrosion protection is cathodic protection, both by the ICCP (Impressed Current Cathodic Protection) and SACP (Sacrificial Anode Cathodic Protection). This study aims to design a cathodic protection with the forced
\end{abstract}


current method (ICCP) for crude oil tanks in an onshore environment and design a cathodic protection for a tower of sutets in a marine environment (offshore). The research began with a literature study, then continued with the data collection stage, both primary and secondary data. Followed by the design phase of the ICCP crude oil tank on land and the SACP tower design in the sea sutet. After the design and installation is completed, the validation stage proves that the design is correct and meets the corrosion protection criteria. The results of the ICCP crude oil tank design require $4 \mathrm{MMO}$ Tubular Titanium anodes with a transformer capacity of 3.02 $\mathrm{kVA}$ and 24 Volt DC voltage. As for the SACP design, the tower tower requires $4 \mathrm{Al}-\mathrm{Zn}-\mathrm{In}$ Alloy anodes and the weight of each anode is $25 \mathrm{~kg}$ with an anode capacity of $2464 \mathrm{~A} . \mathrm{hr} / \mathrm{kg}$.

Keywords : corrosion, cathodic protection, impressed current, sacrificial anode.

\section{PENDAHULUAN}

Korosi menjadi masalah yang paling sering terjadi pada struktur baja baik yang berada di darat maupun laut. Kerusakan akibat korosi bisa mengurangi kekuatan struktur yang akan berakibat pada kerusakan permanen sehingga struktur tersebut tidak bisa lagi digunakan sesuai fungsinya. Hal ini bisa menyebabkan banyak kerugian, antara lain kerugian biaya perbaikan atau instalasi, biaya terganggunya pemenuhan kebutuhan masyarakat dan yang lebih mengerikan adalah potensi kecelakaan kerja yang bisa menyebabkan kematian. Oleh karena itu, sangat penting untuk bisa melindungi struktur baja dari bahaya korosi, dimulai dari proses perancangan sehingga potensi korosi dapat dikurangi dan dikendalikan.

Beberapa metoda penanggulangan korosi yang populer digunakan di dunia industri saat ini adalah metoda pelapisan (coating) dan proteksi katodik. Pada kondisi-kondisi tertentu seperti struktur baja di laut kombinasi antara metoda coating dan proteksi katodik merupakan pilihan terbaik untuk perlindungan korosi [1]. Suatu struktur dikatakan terproteksi korosi dengan baik jika nilai potensialnya sama atau lebih negatif dari $-850 \mathrm{mV}$ jika menggunakan elektroda acuan $\mathrm{Cu} / \mathrm{CuSo} 4$ atau $-805 \mathrm{mV}$ jika menggunakan elektroda acuan $\mathrm{Ag} / \mathrm{AgCl}\left[{ }^{2]}[3]\right.$. Secara umum range potensial optimum dari struktur baja adalah - $805 \mathrm{mV}$ sampai $-1000 \mathrm{mV}$ dengan elektroda acuan $\mathrm{Ag} / \mathrm{AgCl}\left[{ }^{4]}\right.$. Tetapi range nilai potensial ini bisa berubah tergantung kondisi lingkungan. Prinsip kerja proteksi katodik dengan cara menghubungkan struktur baja yang akan dilindungi dengan metal lain yang memiliki nilai potensial lebih rendah (SACP) atau dengan mengalirkan arus listrik melalui anoda eksternal (ICCP). Dengan begitu nilai potensial struktur tersebut akan turun dibawah nilai potensial kriteria proteksi yaitu sebesar $-805 \mathrm{mV}$ vs $\mathrm{Ag} / \mathrm{AgCl}{ }^{[4]}$.

Banyak faktor yang mempengaruhi keberhasilan dari perancangan proteksi katodik baik tipe anoda korban (SACP) maupun tipe arus paksa (ICCP), antara lain kondisi lingkungan, identifikasi zona proteksi, kebutuhan arus proteksi, pemilihan anoda, dll. Sudah banyak penelitian ataupun studi yang dilakukan dalam rangka desain / perencanaan proteksi katodik untuk struktur di laut maupun di darat.

Beberapa penelitian yang berhubungan dengan perencanaan proteksi katodik baik juga pernah dilakukan. Leheta ${ }^{[5]}$ pernah melakukan perancangan proteksi katodik untuk struktur baja di lingkungan lepas pantai (offshore). Di dalam penelitiannya, Leheta membandingkan antara desain ICCP dan SACP dengan menggunakan program $C^{++}$untuk mendapatkan jumlah, berat dan usia pakai anoda untuk struktur offshore platform dan jack up rig. Liu $\mathrm{dkk}^{[6]}$ merancang proteksi katodik untuk grounding body pada tower tegangan tinggi yang ada di Guangzhou, China. Dalam penelitiannya dijelaskan bahwa tahap perancangan dari SACP meliputi tahap penentuan potensial proteksi dan rapat arus proteksi, perhitungan kebutuhan arus proteksi, perhitungan 
tahanan grounding anoda, pemilihan anoda, perhitungan arus output anoda, perhitungan massa dan jumlah anoda dan penentuan letak anoda pada struktur. Maurilio dan Hoffman ${ }^{[7]}$ merancang ICCP untuk tower listrik tegangan tinggi dengan memanfaatkan induksi dari tower. Tegangan listrik DC didapatkan dengan menggunakan medan listrik yang dihasilkan oleh saluran transmisi itu sendiri.

Dari uraian latar belakang di atas, kita mengetahui bahwa sangat penting untuk melindungi tangki minyak dan tower sutet dari korosi. Tingkat korosi yang paling parah terjadi di bagian struktur yang contact dengan air laut ataupun tanah sebagai elektrolit.). Oleh karena itu perancangan proteksi katodik pada tangki minyak fokus pada bagian bawah tangki dan tower sutet fokus pada area percikan dan terendam.

Sejauh yang penulis ketahui dari berbagai referensi dan jurnal penelitian, saat ini belum ada perancangan proteksi korosi pada tower sutet yang menggunakan proteksi katodik dengan metoda anoda korban. Perancangan ini bertujuan untuk membuat perencanaan proteksi katodik dengan metoda anoda korban (SACP) arus paksa dengan kombinasi coating untuk struktur tower sutet di laut dan proteksi katodik dengan metoda arus paksa (ICCP) untuk struktur tangki minyak mentah di darat. Objek penelitian yang digunakan mengambil data struktur tangki minyak mentah dan data parameter lingkungan di Kalimantan. Penelitian ini diharapkan bisa menjadi panduan yang sistematis untuk perancangan proteksi katodik untuk struktur baja yang berada di lingkungan darat (onshore) maupun laut (offshore).

\section{METODE PENELITIAN}

Penelitian ini diawali dengan studi literatur untuk mendapatkan konsep desain proteksi katodik, parameter operasi dan lingkungan yang berpengaruh, metoda perhitungan, dan parameter keberhasilan desain sebuah proteksi katodik. Kemudian dilakukan tahap pengumpulan data. Data yang digunakan pada penelitian ini didapatkan baik dari data lapangan, data dari literatur maupun data dari hasil perhitungan. Dilanjutkan dengan tahap desain ICCP untuk tangki minyak mentah di darat dan validasi desain untuk membuktikan bahwa desain yang dilakukan sudah tepat dan memenuhi kriteria proteksi korosi untuk struktur logam. Setelah itu dilanjutkan desain SACP untuk tower sutet di laut.

\subsection{Desain ICCP Tangki Minyak Mentah di Darat}

Bagian dari struktur tangki minyak mentah yang akan diproteksi katodik adalah bagian yang selalu contact dengan tanah (elektrolit), antara lain bottom tank, grounding rod dan copper ring. Luas area total dari bagian-bagian tersebut adalah $3021.16 \mathrm{~m}^{2}$.

Nilai resistivitas tanah yang berfungsi sebagai elektrolit adalah $10000 \Omega \mathrm{cm}$. Nilai tersebut tingkat korosivitas nya dikategorikan sebagai Slightly Corrosive[6]. Temperatur lingkungan di area tangki minyak mentah ditentukan $30^{\circ} \mathrm{C}\left(70^{\circ} \mathrm{F}\right)$.

Pengukuran nilai potensial dari tangki minyak biasanya menggunakan elektroda acuan $\mathrm{Ag} / \mathrm{AgCl}$. Kriteria proteksi korosi yang disyaratkan adalah kurang dari $-805 \mathrm{mV}$ terhadap elektroda acuan $\mathrm{Ag} / \mathrm{AgCl}\left[{ }^{[8]}\right.$. Nilai proteksi tersebut sesuai dengan nilai yang disarankan dari beberapa literatur dan standar internasional yang umum digunakan sebagai referensi desain proteksi katodik $[9,10]$.

Perhitungan kebutuhan arus proteksi didapatkan dari persamaan:

$$
I_{C}=A_{C} \cdot \frac{i_{C}}{1000} \cdot f_{C} \cdot(1+S F)
$$

Nilai kebutuhan arus proteksi ini dipengaruhi oleh luas area dari struktur yang akan diproteksi katodik $\left(A_{c}\right)$, faktor kerusakan cat $\left(f_{c}\right)$ dan rapat arus $\left(i_{c}\right)$. Nilai $f_{c}$ adalah $100 \%$ 
karena struktur tidak di cat dan ditambahkan safety factor 25\% sebagai faktor keamanan jika terjadi perubahan parameter operasi selama masa layanan dari ICCP yaitu 10 tahun. Anoda yang dipilih untuk desain ICCP ini adalah tipe Tubular MMO (Mixed Metal Oxyde) Titanium dengan spesifikasi bisa dilihat pada Tabel 1. di bawah.

Tabel 1. Spesifikasi Anoda ICCP

\begin{tabular}{|l|l|}
\hline \multicolumn{1}{|c|}{ Anoda } & \multicolumn{1}{c|}{ Spesifikasi } \\
\hline Tipe & Tubular MMO Titanium \\
\hline Diameter & $0.032 \mathrm{~m}$ \\
\hline Panjang & $1.25 \mathrm{~m}$ \\
\hline Luas Area & $0.125 \mathrm{~m} 2$ \\
\hline Rapat Arus & $99760 \mathrm{~A} / \mathrm{m} 2$ \\
\hline Arus Output & $12438 \mathrm{~A}$ \\
\hline Canister & Steel Pipe \\
\hline
\end{tabular}

(Sumber: data manufaktur)

Perhitungan kebutuhan anoda didapatkan dari persamaan:

$$
Q_{A}=\frac{I_{C}}{I_{A}}
$$

Jumlah anoda yang dibutuhkan adalah hasil pembagian dari kebutuhan arus proteksi struktur $\left(I_{C}\right)$ dengan arus output dari anoda yang digunakan $\left(I_{A}\right)$. Dilanjutkan dengan perhitungan kebutuhan trafo rectifier untuk kebutuhan supply arus listrik dalam sistem ICCP ini. Nilai tahanan (resistance) sirkuit DC total didapatkan dari penjumlahan tahanan anoda terhadap tanah dan tahanan kabel dari sistem. Persamaan yang digunakan adalah:

$$
\begin{aligned}
& R_{g b}=\frac{R_{a}}{F} \cdot N \\
& F=1+\frac{\rho}{\pi \cdot S \cdot R_{a}} \cdot \ln 0.656 N \\
& R_{\text {cable }}=\frac{L_{c} \cdot R_{e}}{N} \\
& \frac{1}{R_{p}}=\frac{1}{R_{g b}}+\frac{1}{R_{\text {cable } 2}}+\frac{1}{R_{\text {cable } 33}}+\frac{1}{R_{\text {cable } 4}} \\
& R_{n}=R_{\text {cable } 5}+R_{\text {cable } 6} \\
& R_{t}=R_{p}+R_{n}
\end{aligned}
$$

Dimana $R_{g b}=$ tahanan anoda-tanah, $R_{p}=$ tahanan sirkuit DC positive, $R_{n}=$ tahanan sirkuit DC negative, $R_{T}=$ tahanan sirkuit DC total, $R_{a}=$ tahanan satu anoda, $F=$ faktor interferensi, $\mathrm{N}=$ jumlah anoda, $F=$ faktor interferensi multiple anode, $\rho=$ resistivitas tanah (ohm.cm), $\mathrm{S}=$ jarak antar anoda (m).

Kebutuhan tegangan trafo rectifier yang dibutuhkan didapatkan dari persamaan:

$$
E_{t}=I_{T} \cdot R_{t} \cdot(1+S F)+B_{E M F}
$$




$$
\begin{aligned}
& I_{A C}=\frac{E_{D C} \cdot I_{D C}}{E_{A C} \cdot E f f \cdot \sqrt{3}} \\
& P_{A C}=I_{A C} \cdot E_{A C} \cdot \sqrt{3}
\end{aligned}
$$

Dimana $E_{t}=$ kebutuhan tegangan output DC (V), $I_{T}=$ kebutuhan arus $(\mathrm{A}), R_{t}=$ tahanan total DC (ohm), $S F=$ safety factor $(25 \%), B_{E M F}=$ back electromotive voltage (2 volt), $I_{A C}=$ arus input $\mathrm{AC}(\mathrm{A}), P_{A C}=$ kapasitas $\mathrm{TR} /$ trafo rectifier $(\mathrm{kVA}), E_{A C}=$ tegangan input $\mathrm{AC}$ (volt), $I_{D C}=$ arus input DC (A), $E_{D C}=$ tegangan input DC (volt), $E f f=$ efisiensi transformer $(80 \%)$.

\subsection{Instalasi Desain ICPP Tangki Minyak Mentah di darat}

Setelah desain ICCP selesai, maka dilanjutkan dengan pekerjaan instalasi ICCP ini di lapangan. Anoda akan dipasang dengan menggunakan groundbed dengan diameter 6 in dan panjang tabung 2 meter. Anode groundbed dipasang pada kedalaman satu meter. Desain ini untuk memastikan polarisasi proteksi katodik untuk kedua struktur terdistribusi secara merata. Skema instalasi dan lokasi pemasangan anoda, trafo rectifier, junction box dan accessories lainnya bisa dilihat pada Gambar 1. di bawah.

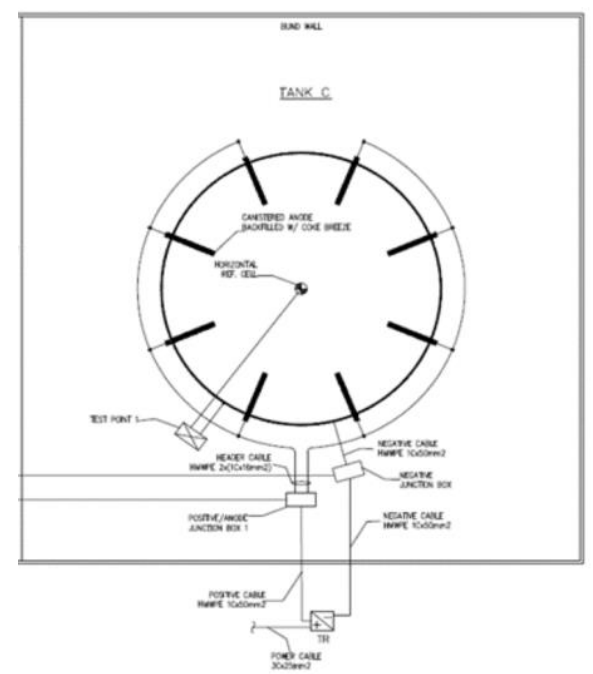

Gambar 1. Skema Instalasi ICCP Tangki Minyak di Darat

\subsection{Desain SACP Tower Sutet di Laut}

Struktur tower sutet yang dijadikan objek penelitian untuk desain SACP ini menggunakan salah satu tower sutet PLN dengan tipe BB6 + 3M SLIM dengan ketinggian total 38 meter. Karena lokasinya di lingkungan laut (offshore), tower sutet ini dibagi menjadi 3 zona, yaitu zona atmosfer (atmospheric rone) dengan tinggi 31 meter, zona percikan (splash rone) dengan tinggi 2 meter dan zona terendam (submerged zone) dengan tinggi 5 meter. Zona atmosfer akan menggunakan perlindungan korosi dengan metoda coating, sedangkan zona percikan dan zona terendam akan menggunakan kombinasi antara metoda coating dengan proteksi katodik anoda korban (SACP). 
Parameter lingkungan untuk desain SACP tower sutet ini menggunakan parameter lingkungan antara lain nilai resistivitas air laut (elektrolit) sebesar $1900 \Omega \mathrm{cm}$, resistivitas tanah sebesar $3500 \Omega \mathrm{cm}$, kedalaman air laut sekitar 5 meter dan temperatur lingkungan $68^{\circ} \mathrm{F}$.

Pemilihan proteksi cat (coating) untuk zona splash dan zona terendam merupakan salah satu faktor penting dalam keberhasilan sistem proteksi korosi tower sutet ini. Lapisan cat (coating) yang digunakan dalam desain SACP ini sesuai dengan rekomendasi DNV untuk lapisan cat marine application, menggunakan epoxy coat kategori III, yaitu dengan dua atau lebih lapisan cat marine berbasis epoxy, polyurethane atau vynil, dengan total DFT $350 \mu \mathrm{m}^{[7]}$. Dari banyak penelitian dan aplikasi praktisi di lapangan, coatings jenis ini yang paling efektif sebagai pengendali korosi dengan metoda pelapisan (coatings).

Perhitungan nilai kebutuhan arus proteksi untuk desain SACP sama dengan ICCP menggunakan persamaan (1) seperti yang ditulis di atas. Kebutuhan arus proteksi ini dipengaruhi oleh luas area dari struktur yang akan diproteksi katodik $\left(A_{c}\right)$, faktor kerusakan cat $\left(f_{c}\right)$ dan rapat arus $\left(i_{c}\right)$. Area yang akan diproteksi katodik meliputi zona percikan dan zona terendam dengan luas area permukaan sebesar $22.45 \mathrm{~m}^{2}$ untuk zona percikan dan $56.12 \mathrm{~m}^{2}$ untuk zona terendam. Untuk nilai faktor kerusakan cat dan rapat arus mengikuti rekomendasi dari standar internasional DNV-RP-B401[7].

Anoda yang dipilih untuk desain SACP ini adalah jenis Aluminium dengan campuran 3\% Zn-In. Spesifikasi anoda bisa dilihat pada Tabel 2. di bawah.

Tabel 2. Spesifikasi Anoda SACP

\begin{tabular}{l|l}
\hline Anoda & Spesifikasi \\
\hline Jenis & Al-Zn-In Alloy \\
\hline Diameter & $50 \mathrm{~cm}$ \\
\hline Panjang & $100 \mathrm{~cm}$ \\
\hline Massa & $25 \mathrm{~kg}$ \\
\hline Kapasitas & 2464 A. hr $/ \mathrm{kg}$ \\
\hline Potential Drop & $-0.815 \mathrm{Volt}$ \\
\hline Anode Connection & Welded \\
\hline
\end{tabular}

(Sumber: data manufaktur)

Perhitungan kebutuhan massa total anoda didapatkan dari persamaan:

$$
M=\frac{I_{C} \cdot t .8760}{u \cdot C}
$$

Nilai kebutuhan massa total anoda dipengaruhi oleh arus total proteksi yang dibutuhkan sistem $\left(I_{C}\right)$, kapasitas anoda $(\mathrm{C})$, masa layanan dari SACP $(\mathrm{t})$ dan faktor utilisasi (u) yang ditentukan nilainya adalah 0.9 .

Dilanjutkan dengan perhitungan tahanan anoda dan arus output anoda, yang didapatkan dari persamaan:

$$
\begin{aligned}
& R_{\text {air }}=\frac{\rho}{2 \pi L}\left\{\ln \left(\frac{4 L}{r}\right)-1\right\} \\
& I_{a}=\frac{\left(E_{1}-E_{1^{\prime}}\right)-E_{2}}{R}
\end{aligned}
$$


Dimana $\mathrm{R}=$ tahanan anoda dalam air (ohm), $\rho=$ resistivitas air (ohm.cm), $\mathrm{L}=$ panjang anoda $(\mathrm{cm}), \mathrm{r}=$ jari-jari anoda $(\mathrm{cm}), I_{a}=$ arus yang dihasilkan anoda $(\mathrm{A}), E_{1}=$ potensial anoda $(\mathrm{V}), E_{1},=$ potensial drop $(\mathrm{V}), E_{2}=$ potensial struktur $(\mathrm{V})$.

\section{HASIL DAN PEMBAHASAN}

\subsection{Hasil Perancangan ICCP Tangki Minyak Mentah di Darat}

Area yang akan diproteksi oeh ICCP meliputi bagian bawah dari tangki yang mengalami kontak dengan tanah (tank bottoms), grounding rod dan copper ring. Hasil perhitungan luas area dan kebutuhan arus proteksi yang dibutuhkan pada sisitem ICCP ini dapat dilihat pada Tabel 3. di bawah.

Tabel 3. Luas Area dan Kebutuhan Arus Proteksi ICCP

\begin{tabular}{l|l|l|l|l}
\hline Struktur & $\begin{array}{l}\text { Panjang } \\
(\mathbf{m})\end{array}$ & $\begin{array}{l}\text { Diameter } \\
(\mathbf{m})\end{array}$ & $\begin{array}{l}\text { Luas Area } \\
\left(\mathbf{m}^{\mathbf{2}}\right.\end{array}$ & $\begin{array}{l}\text { Kebutuhan Arus } \\
(\mathbf{A})\end{array}$ \\
\hline Steel Tank Bottom & 0.3 & 61.38 & 3014.34 & 37.675 \\
\hline Grounding Rod & 3 & 0.02 & 0.18 & 0.00225 \\
\hline Copper Ring & 211.67 & 0.01 & 6.64 & 3.32 \\
\hline Total Tangki & 3021.16 & 40.99 \\
\hline
\end{tabular}

Dari hasil perhitungan didapatkan kebutuhan arus proteksi total untuk tangki adalah 32.8 A. Arus proteksi ini ditambahkan safety factor 25\% untuk mengantisipasi perubahan parameter operasi dan lingkungan selama masa layanan 10 tahun, sehingga arus proteksi total yang dibutuhkan oleh sistem ICCP ini sebesar 41 A.

Kebutuhan jumlah anoda untuk sistem ICCP ini didapatkan dari hasil perhitungan dengan persamaan (2) yaitu empat buah anoda. Anoda akan dipasang dengan menggunakan groundbed dengan diameter 6 in dan panjang tabung 2 meter. Anode groundbed dipasang pada kedalaman satu meter. Desain ini untuk memastikan polarisasi proteksi katodik untuk kedua struktur terdistribusi secara merata.

Nilai tahanan total sirkuit DC merupakan penjumlahan dari tahanan positif DC dan tahanan negatif DC. Hasil perhitungan tahanan positif DC yang didapatkan dari persamaan (6) bisa dilihat pada Tabel 4. di bawah, sedangkan tahanan negatif DC yang didapatkan dari persamaan (7) bisa dilihat pada Tabel 5. di bawah.

Tabel 4. Tahanan Positif Sirkuit DC

\begin{tabular}{|c|c|c|c|c|c|}
\hline \multirow[b]{2}{*}{$\begin{array}{l}\text { Tank OD and } \\
\text { Electrical } \\
\text { Grounding System }\end{array}$} & \multirow[b]{2}{*}{$\begin{array}{l}\text { Anode +Ground bed } \\
\text { Resistance }\end{array}$} & \multicolumn{3}{|c|}{ Cable Resistance } & \multirow[b]{2}{*}{ Total } \\
\hline & & $\begin{array}{l}\text { Anode } \\
\text { Tail }\end{array}$ & $\begin{array}{l}\text { Anode } \\
\text { Header } \\
\text { to } P J B\end{array}$ & $\begin{array}{l}\text { Positive } \\
\text { Cable } \\
\text { to } T R \\
\end{array}$ & \\
\hline Tangki & 3.173 & 0.002 & 0.069 & 0.046 & 3.290 \\
\hline \multicolumn{5}{|l|}{$1 / \mathrm{R}$} & $1 / 3.290$ \\
\hline \multicolumn{5}{|c|}{ Tahanan Sirkuit Positif DC } & 0.304 \\
\hline
\end{tabular}


D. Sumantri dan P. T. Iswanto. / Journal of Mechanical Design and Testing 2(2), (2020), 77-86

Tabel 5. Tahanan Negatif Sirkuit DC

\begin{tabular}{|c|c|c|c|c|c|c|}
\hline \multirow{2}{*}{$\begin{array}{l}\text { Tank and } \\
\text { Electrical Grounding System }\end{array}$} & \multirow{2}{*}{$\begin{array}{l}\text { Insulatio } \\
n \\
\text { Type }\end{array}$} & Size & $\begin{array}{l}\text { Ratin } \\
g \text { at } 30 \\
C\end{array}$ & $\boldsymbol{R}_{\boldsymbol{e}}$ & $\mathbf{N}$ & $\boldsymbol{R}$ \\
\hline & & $\begin{array}{l}\mathrm{mm} \\
2\end{array}$ & Amp & $\begin{array}{l}\text { Ohm/ } \\
\text { m }\end{array}$ & $\begin{array}{l}\text { pc } \\
\text { s }\end{array}$ & ohm \\
\hline Tahanan Kabel Struktur ke NJB & HMWPE & 50 & 185 & 0.000387 & 1 & $\begin{array}{l}0.0077 \\
4\end{array}$ \\
\hline Tahanan Kabel NJB ke Trafo & HMWPE & 50 & 240 & 0.000387 & 1 & 0.046 \\
\hline \multicolumn{6}{|l|}{ DC Negative Circuit Resistance } & 0.0534 \\
\hline
\end{tabular}

Tahanan total sirkuit DC adalah 0.357 Ohm. Kebutuhan trafo rectifier adalah: $E_{t}=$ 16.5 Volt $D C \cong 24$ Volt $D C, I_{A C}=4.2$ Ampere dan $P_{A C}=3.02 \mathrm{kVA}$. Nilai tegangan output DC adalah $E_{t}=16.5$ volt dan nilai tegangan output $\mathrm{AC}$ adalah $P_{A C}=3.02 \mathrm{kVA}$. Dari hasil perhitungan tegangan AC dan DC ini maka trafo rectifier yang dipilih dengan tegangan DC 24 Volt dan arus DC 100 Volt dengan kapasitas trafo $3.02 \mathrm{kVA}$.

Pada sistem proteksi ICCP ketersediaan arus listrik menjadi suatu keharusan, karena perpindahan elektron dari anoda ke katoda terjadi karena adanya arus listrik eksternal yang mengalir di dalam sistem. Jika sumber arus listrik hilang maka struktur akan menjadi tidak terproteksi. Oleh karena itu dibutuhkan UPS (Uninterruptable Power Supply) atau battery untuk mengantisipasi jika daya listrik yang mensupply sistem ICCP hilang. Spesifikasi UPS yang dipilih disesuaikan dengan spesifikasi battery dan trafo yang digunakan.

\subsection{Hasil Perancangan SACP Tower Sutet di Laut}

Perhitungan kebutuhan arus proteksi yang dibutuhkan dalam sistem SACP ini sama dengan ICCP, yaitu menggunakan persamaan (1). Untuk nilai faktor kerusaan cat didapatkan dari persamaan:

$$
f_{c}=a+b . L
$$

dengan nilai $\mathrm{a}=0.02, \mathrm{~b}=0.012$ dan $\mathrm{L}=$ umur masa layan 10 tahun. Sedangkan nilai rapat $\left(i_{c}\right)$ digunakan nilai $150 \mathrm{~mA} / \mathrm{m} 2$ untuk kondisi initial, $70 \mathrm{~mA} / \mathrm{m} 2$ untuk kondisi mean dan 100 $\mathrm{mA} / \mathrm{m} 2$ untuk kondisi final. Ditambahkan dalam perhitungan safety factor $25 \%$ sebagai faktor keamanan jika terjadi perubahan parameter operasi selama masa layanan dari SACP yaitu 20 tahun. Hasil perhitungan luas area dan arus proteksi yang dibutuhkan sistem bisa dilihat pada Tabel 6. di bawah.

Tabel 6. Luas Area dan Kebutuhan Arus Proteksi SACP

\begin{tabular}{|c|c|c|c|c|c|c|c|c|c|}
\hline \multirow[t]{2}{*}{ Area } & \multirow[t]{2}{*}{ Period } & \multirow{2}{*}{$\begin{array}{c}\text { Luas } \\
\text { Permukaan } \\
\left(\mathrm{m}^{2}\right)\end{array}$} & \multirow{2}{*}{$\begin{array}{c}i c \\
\left(\mathrm{~mA} / \mathrm{m}^{2}\right)\end{array}$} & \multicolumn{3}{|c|}{$\begin{array}{c}\text { Parameter } \\
\text { kerusakan cat }\end{array}$} & \multirow{2}{*}{$\begin{array}{l}F c \\
(\%)\end{array}$} & \multirow{2}{*}{$\begin{array}{l}\text { Sf } \\
(\%)\end{array}$} & \multirow{2}{*}{$\begin{array}{c}\text { Arus } \\
\text { Proteksi } \\
\text { (A) }\end{array}$} \\
\hline & & & & $t$ & $a$ & b & & & \\
\hline \multirow{3}{*}{$\begin{array}{l}\text { Area Splash } \\
\text { Zone }\end{array}$} & initial & 22.45 & 150 & 0 & 0.02 & 0.012 & 2 & 25 & 0.084 \\
\hline & mean & 22.45 & 70 & 10 & 0.02 & 0.012 & 14 & 25 & 0.275 \\
\hline & final & 22.45 & 100 & 20 & 0.02 & 0.012 & 26 & 25 & 0.729 \\
\hline \multirow{3}{*}{$\begin{array}{l}\text { Area } \\
\text { Submerged }\end{array}$} & initial & 56.12 & 150 & 0 & 0.02 & 0.012 & 2 & 25 & 0.21 \\
\hline & mean & 56.12 & 70 & 10 & 0.02 & 0.012 & 14 & 25 & 0.687 \\
\hline & final & 56.12 & 100 & 20 & 0.02 & 0.012 & 26 & 25 & 1.824 \\
\hline
\end{tabular}


D. Sumantri dan P. T. Iswanto. / Journal of Mechanical Design and Testing 2(2), (2020), 77-86

\begin{tabular}{|l|l|l|}
\hline Total $\begin{array}{l}\text { Tebutuhan } \\
\text { Krus }\left(\mathrm{I}_{\mathrm{t}}\right)\end{array}$ & Initial & 0.294 \\
\cline { 2 - 3 } Mean & 0.962 \\
\cline { 2 - 3 } & Final & 2.553 \\
\hline
\end{tabular}

Perhitungan kebutuhan anoda, tahanan anoda, arus output anoda dan jumlah anoda untuk sistem SACP ini didapatkan dari persamaan-persamaan di atas. Massa anoda total yang dibutuhkan untuk memenuhi masa layanan selama 10 tahun adalah $100.5 \mathrm{~kg}$. Tahanan anoda yang dihasilkan dipengaruhi juga oleh resistivitas elektrolit (air laut) yang dari hasil pengukuran didapatkan nilai 190 ohm.cm. Tahanan anoda yang diperoleh adalah 0.5354 Ohm. Dari nilai tahanan anoda tersebut, arus yang dihasilkan oleh masing-masing anoda yaitu $1.326 \mathrm{~A}$.

Jumlah kebutuhan anoda selama masa desain SACP 10 tahun didapatkan dari total massa anoda yang dibutuhkan sistem dibagi dengan berat setiap anoda, yaitu 4 buah anoda. Semua hasil perhitungan di atas dapat dilihat pada Tabel 7. di bawah.

Tabel 7. Tabel Perhitungan SACP

\begin{tabular}{|l|l|l|}
\hline No. & Deskripsi & Hasil Perhitungan \\
\hline 1 & Kebutuhan Arus Proteksi & 2.553 Ampere \\
\hline 2 & Kebutuhan Massa Anoda & $100.5 \mathrm{~kg}$ \\
\hline 3 & Tahanan Anoda & $5.354 \mathrm{ohm}$ \\
\hline 4 & Arus Output Anoda & 0.1326 Ampere \\
\hline 5 & Kebutuhan Jumlah Anoda & 4 buah anoda \\
\hline
\end{tabular}

Sistem proteksi katodik akan bekerja efektif jika selalu terhubung (contact) dengan elektrolit nya, dalam hal ini adalah air laut. Oleh karena itu untuk penentuan lokasi untuk pemasangan anoda ini harus dipastikan pengukuran tinggi maksimum dan minimum air laut di sekitar tower sutet. Dengan asumsi zona percikan (splash zone) adalah 2 meter dan zona terendam (submerged zone) adalah 5 meter. Tinggi maksimum air laut adalah 7 meter dari dasar laut dan tinggi minimum air laut adalah 5 meter dari dasar laut.

Anoda pada sistem proteksi SACP ini harus ditempatkan pada daerah di bawah permukaan air terendah agar anoda selalu terendam dalam elektrolit (air laut). Maka anoda nantinya akan di pasang pada ketinggian 2 meter dari dasar laut dengan posisi horizontal. Pemasangan anoda dengan metoda horizontal ini untuk mengantisipasi selama masa layanan 10 tahun jika terjadi penurunan level air laut maka anoda akan tetap terendam (terhubung) seluruhnya di dalam elektrolit (air laut).

Dengan jumlah anoda yang dibutuhkan adalah 4 buah, maka anoda akan dipasang pada setiap bagian sisi (4 sisi) tower secara horizontal dengan cara di las pada tiang tower sutet.

\section{KESIMPULAN}

Dari hasil perancangan sistem proteksi katodik ICCP untuk tangki minyak mentah di darat dan tower sutet di laut dapat diambil beberapa kesimpulan, antara lain:

1. Untuk mendapatkan perlindungan korosi tangki minyak di darat dengan masa layanan 10 tahun digunakan proteksi katodik metoda ICCP dengan 4 buah anoda jenis tubular MMO (Mixed Metal Oxide) Titanium. Untuk sumber listrik eksternal membutuhkan tegangan DC sebesar 24 volt DC dan kapasitas trafo $3.02 \mathrm{kVA}$. 
2. Untuk mendapatkan perlindungan korosi tower sutet di laut dengan masa layanan 10 tahun digunakan proteksi katodik metoda SACP dengan 4 buah anoda dimana berat masingmasing anoda $25 \mathrm{~kg}$, dan tipe anoda yang digunakan adalah tipe Al-Zn-In Alloy dengan kapasitas anoda $2464 \mathrm{~A} . \mathrm{hr} / \mathrm{kg}$. Sedangkan kombinasi proteksi coating yang dipilih sesuai DNV-RP-B401-2017 adalah epoxy coat kategori III, yaitu dengan dua atau lebih lapisan cat marine berbasis epoxy, polyurethane atau vynil, dengan total DFT $350 \mu \mathrm{m}$.

\section{DAFTAR PUSTAKA}

Bardal, E., 2004, Corrosion and Protection, Springer, Trondheim

Baxter, D., Britton, J. (2013), Offshore Cathodic Protection 101 What Is It and How Does It Work, Deepwater [Online]. Available : http://www.cathodicprotection101.com/

Diedericks, D. E., Schoor, G. V., Ranft, E. O., 2019, Cathodic Protection System Design Framework, SAUPEC/RobMech/PRASA Conference Bloemfontein, South Africa, January 28-30.

DNVGL-RP-B401. (2017), Cathodic Protection Design, Recommendation Industry Practice.

ISO-15589-2. (2004), Petroleum, petrochemical and natural gas industries - cathodic protection of pipeline transportation sistems, Second edition 2012-12-01, International Standard.

Ivanov, H., 2016, Corrosion Protection System in Offshore Structures, Honours Research Project, University of Akron.

Leheta, H. (2008), Cathodic Protection Design Procedure for Steel Offshore Structures, Alexandria University, Egypt.

Liu, R., Huang, P., Mo, J., 2015, Anti Corrosion Design of Grounding Body in Power Transmission Line with Cathode Protection Method, Second International IFEEA, China Electric Power Research Institute, China.

Maurilio da Silva, J., Hoffman, J.N., 2001, Cathodic Protection for Tower Foundation Using Induction From The Transmission Line Electric Field, International Conference Paper, Companhia Paranaense de Energia.

Meillier, A., Court, H., Park, S. (2003), A Review of Galvanic Anode Cathodic Protection Design Procedure, Corrosion Control Services Limited, Stafford Park, Telford, UK.

Peabody, A.W., 2005, Control of Pipeline Corrosion, NACE International, the Corrosion Society, Houston, Texas - 77084.

Shreir, L. L. (1990). Design and Operational Guidance on Cathodic Protection of Offshore Structures, Subsea Installations and Pipelines, London: MTD Ltd Publication.

Stutzmann, J., 2017, Cathodic Corrosion Protection in the Context of Lifetime Extension of Monopile-based Offshore Wind Turbines. Thesis, Department of Materials and Manufacturing Technology, Chalmers University of Technology, Gothenburg, Sweden

Tiwari. A., Hihara, L., Rawlins, J. (2014), Intelligent Coating for Corrosion Control, International Conference Journal.

Veronelli, L. A., 2012, Empirical and Computer Aided Design of Cathodic Protection Systems, Paperpresented at the Politecnico Di Milano. 